\title{
Three-Dimensional Numerical Study of the Anode Supported Intermediate Temperature Solid Oxide Fuel Cell Overheating
}

\author{
Sahli Youcef ${ }^{1}$, Zitouni Bariza $^{2}$, Moungar Houcine ${ }^{1 *}$, Ben-moussa Hocine ${ }^{3}$ \\ ${ }^{1}$ Unité de Recherche en Energies Renouvelables en Milieu Saharien, URERMS, Centre de Développement des Energies \\ Renouvelables, CDER, 01000, Adrar, Algeria \\ ${ }^{2}$ Department of Food Technology, Institute of Veterinary Sciences and Agronomic Sciences, University of Batna 1, Algeria \\ ${ }^{3}$ Laboratoire d'Etude des Systèmes Energétiques Industriels (LESEI), Département de Mécanique, Faculté de Technologie, \\ Université Batna 2, Algeria
}

Corresponding Author Email: h.moungar@urerms.dz

https://doi.org/10.18280/ijht.370419

Received: 27 January 2019

Accepted: 24 November 2019

\section{Keywords:}

AS-IT-SOFC, heating, concentration source, activation source, electrochemical source, Ohmic source

\begin{abstract}
The purpose of the present work is to carry out an overheating study of planar solid oxide fuel cells at supported anode that operate at an intermediate temperature (AS-IT-SOFC) according to a three-dimensional and stationary numerical model. In this work, the heat is supposed produced according to four processes of heat generation (the Ohmic source that is due to the Joule effect, the source due to the species concentrations, the activation source that is caused by activation of different chemical reactions produced in the two electrodes, the electrochemical source due to the water formation in the anode). The results are obtained from a FORTRAN language program realized locally, which is based on the finite difference method in a three-dimensional environment. From the obtained results analysis, it became apparent that the developed model for the AS-IT-SOFC overheating study allowed us to understand the impact of each heat source on the temperature elevations and distributions in AS-IT-SOFC. The greatest heat production is that generated by the Ohmic source, it is about $80.6 \%$ for gas inlet temperatures of $883 \mathrm{~K}$. The smallest heat production is that obtained by the source of concentration that is negligible compared to other sources. The heat produced by the electrochemical source is greater than that generated by the activation source, their heat productions are almost 17 and $2.3 \%$ for gas inlet temperatures of $883 \mathrm{~K}$ respectively.
\end{abstract}

\section{INTRODUCTION}

SOFCs present a promoter technology of energy production because of their high electrical efficiency $(\sim 65-70 \%)$ and exergetic efficiency ( 90-95\%). The drawbacks of the hightemperature operation $\left(600-1000^{\circ} \mathrm{C}\right)$ of these cells appear as very high thermal stresses and very large start-up time. When the SOFC operating temperature is truly high, large temperature differences to develop inside the cells resulting in severe operating conditions in the form of truly important thermal stresses. In addition, high operating temperatures inevitably require a long time of startup. [1].

IT-SOFCs are SOFCs that operate at an intermediate temperature $\left(200-600^{\circ} \mathrm{C}\right)$ [2]. Their operation at an intermediate temperature lower the resulting thermal stresses and the startup time. Sohn et al [3] have developed a twodimensional model to simulate the operation of planar solid oxide fuel cells with a supported anode that operates at an intermediate temperature (AS-IT-SOFC) and fed with partially reformed methane. The model presented by Sohn et al. [3] takes into account the reforming of methane inside the anode (DIR). Yang et al. [4] have developed a 3D model of an AS-IT-SOFC by ANSYS / Fluent commercial code to evaluate the methane vapor reforming reactions in the anode and the water formation and carbon dioxide in the active layer of the anode.

Lee et al. [5] have presented a multi-scale simulation technique for a new 5-cell planar design of micro-oxide (mSOFC) to determine the optimum composition of an electrolyte capable of operating in the intermediate temperature interval without sacrificing performance. Various samarium doped cerium oxide (SDC) electrolyte compositions in operating temperatures of 673 to $1023 \mathrm{~K}$ are being investigated to identify maximum ionic conductivity. They have mentioned that the YSZ electrolyte has given better results. Andersson et al. [6] have used a coupled fluid dynamics approach that is based on the finite element method in three dimensions to study an IT-SOFC. They have presented a parametric comparison between three cell designs.

In the continuation of our works [7-19], where the thermodynamic ( 0 D) has been employed to obtain the influence and behavior of all over-potentials (Ohmic, concentration and activation) on the produced power density by SOFCs [7]. Thermodynamic optimization studies of the solid oxide fuel cell (SOFC) to maximizing the produced power density have been presented using two different thermodynamic models (0 D) [8-9].

The thermoelectric performance of the intermediate temperature SOFC has been presented by a one-dimensional model ( $1 \mathrm{D})$ using the finite volume method. The heat is generated by the Ohmic loss and the electrochemical loss due to the internal electrochemical reactions [10]. The power density and the hydrogen consumption of a planar SOFC have been studied according to the input parameters; such as the 
operating temperature, the operating pressure, the flow rates and the mass fractions by a one-dimensional electro-dynamic model (1 D), that cantabiles the heat production from the Ohmic and activation losses, using the finite difference method [15].

The water and hydrogen distributions depending on the anode thickness in SOFC heart have been obtained by a twodimensional model (2 D) based on the finite difference method in the perpendicular plane to the reactive gas flow directions, when the heat is generated by the Ohmic, activation and electrochemical losses [11]. The finite difference method in 2 $\mathrm{D}$ has been employed to investigate and obtain the temperature fields in the perpendicular plane to the gas flow of a planar SOFC heart at a supported anode under only the chemical reactions effect [12].

A 2 D numerical study of the determination and location of the maximum temperature values in all cell parts (electrolyte, interconnectors, anode and cathode) of a planar SOFC at a supported electrolyte or a supported anode, in a perpendicular plane to the gas flow under the polarization effects: concentration, Ohmic and activation has been conducted [13]. A $2 \mathrm{D}$ analysis of the heat production and distribution in all porous and solid parts of a planar SOFC at a supported anode under the effect of various over-potentials (activation, Ohmic, chemical and concentration), in the perpendicular plane to the gas flow direction in order to describe the thermal behavior during the operation has been shown [14]. A comparative study of the heat distribution depending on the gas supply temperature between two planar SOFC configuration types (supported anode and supported electrolyte) for the cases with and without the total heat source (activation, Ohmic, chemical and concentration), in all cell parts (interconnectors, electrolyte and electrodes) has been presented [16]. The molar fractions effect of the fuel constitutive chemical species $\mathrm{CCH}_{4}$, $\mathrm{H}_{2} \mathrm{O}, \mathrm{CO}, \mathrm{CO}_{2}$ and $\mathrm{H}_{2}$ ) on the heat distribution has been studied in the planar SOFC at the supported anode in a twodimensional environment (2 D) and perpendicular to the gas flow direction. The heat generation/absorption due to the direct internal reforming in all cell parts have been discussed [17]. A study of the produced heat behavior by the direct internal reforming depending on the temperature and pressure of the supply fuel in all parts of a planar SOFC at a supported anode in the perpendicular plane to the gas flow using the finite difference method in $2 \mathrm{D}$ has been shown [18].

A comparative study of the heat generation in the three geometric configuration types of the planar SOFC (supported electrolyte, supported anode and supported cathode) in a threedimensional environment (3 D) has been realized considering that the heat production is only caused by the Joule's effect [19].

In this study, we focus on the obtain and analyze of the temperature profiles and distributions in a planar AS-IT-SOFC in a three-dimensional geometry $(3 \mathrm{D})$ according to several types of heat source (Ohmic, activation, concentration, electrochemical, both activation and Ohmic sources and the total source) to determine the impact of each heat source type on the distribution and elevation of the temperature values in all parts of the AS-IT-SOFC (electrolyte, anode, cathode, anodic and cathodic interconnectors and channels). The finite difference method is used for the resolution of partial derivative equations in a three-dimensional environment and steady-state numerical condition. A program in FORTRAN language is produced to obtain these profiles. In addition, the resulting temperature fields from different heat source cases (Ohmic, activation, concentration, electrochemical, both activation and Ohmic sources and the total source) are compared to the without source case to determine the contribution of each source in the increase and evolution of the temperatures in the AS-IT-SOFC according to several gas inlet temperatures

\section{MATHEMATICAL MODEL}

The computational domain is limited to a single SOFC cell which consists of the cathode, the anode, the electrolyte, the two anodic and cathodic interconnectors and the two anodic and cathodic channels. Figure 1. In this work, the representation of the thermal phenomenon in the planar ITSOFC is governed by the energy equation resulted from energy conservation. Eq. 1. The used model is threedimensional and stationary; the media is considered continuous, the cell components are counted as homogeneous and isotropic, the gases temperature at the inlet of both channels is constant, the heat transfer by radiation is neglected, and the produced current density by the cell is considered constant in all solid parts of the cell. Both gases velocities are assumed low, which leads to the negligence of the convective term.

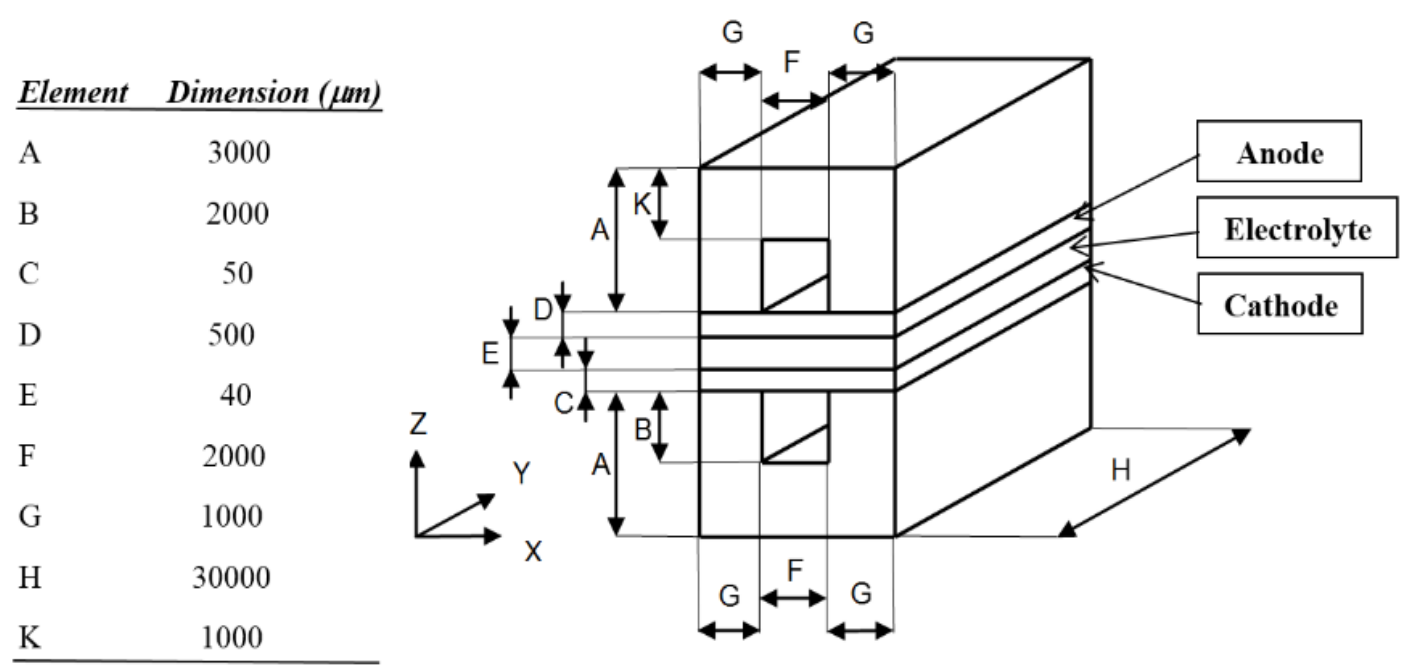

Figure 1. Computational domain 


$$
\frac{\partial}{\partial x}\left(\lambda \frac{\partial T}{\partial x}\right)+\frac{\partial}{\partial y}\left(\lambda \frac{\partial T}{\partial y}\right)+\frac{\partial}{\partial z}\left(\lambda \frac{\partial T}{\partial z}\right)+S=0
$$

where, $\mathrm{x}, \mathrm{y}$ and $\mathrm{z}$ represent the spatial coordinates of each point of the calculation domain, $\mathrm{T}$ is the temperature, $\lambda$ is the thermal conductivity of each component, and $\mathrm{S}$ represents the heat source. The thermal conductivities of the cell component elements are given in the Table 1:

Table 1. Thermal conductivities values

\begin{tabular}{cccc}
\hline Component & $\begin{array}{c}\text { Thermal } \\
\text { conductivity } \\
\boldsymbol{\lambda}\left(\mathbf{W} \cdot \mathbf{m}^{-\mathbf{1}} \mathbf{.} \mathbf{K}^{-1}\right)\end{array}$ & Material & References \\
\hline Anode & 5.84 & $\mathrm{Ni}^{-Y S Z}$ & {$[19-22]$} \\
Cathode & 4 & $\mathrm{La}_{1-\mathrm{x}} \mathrm{Sr}_{\mathrm{x}} \mathrm{MnO}_{3}$ & {$[13,19-20]$} \\
Electrolyte & 2.16 & $\mathrm{YSZ}$ & {$[19-22]$} \\
Interconnector & 6 & $\mathrm{LaCrO}_{3}$ & {$[19,23,24]$} \\
\hline
\end{tabular}

Heat is produced according to the four heat source types: Ohmic, concentration, electrochemical and activation. The heat source caused by the Joule's effect is present in all solid and porous parts. The heat source generated by the activation loss is located in both electrolyte/electrode interfaces. The heat source caused by the concentration of the different species is present in the two electrodes (anode and cathode) and the heat source due to the water formation (electrochemical) is localized in the anode/electrolyte interface.

The heat source due to Ohmic losses $\left(S_{\text {ohm }}\right)$ in each element (anode, cathode, electrolyte and interconnectors) is defined by the ratio of the current density squared and the electrical conductivity of each cell component. Eq. 2.

$$
S_{O h m}=\frac{i^{2}}{\sigma}
$$

$i$ and $\sigma$ represent the current density and the electrical conductivity respectively. The electrical conductivities of the IT-SOFC constructive elements are given by the following Table 2:

Table 2. Electrical conductivities expressions

\begin{tabular}{ccc}
\hline Component & $\boldsymbol{\sigma}\left[\mathbf{\Omega}^{-1} \cdot \mathbf{c m}^{-1}\right]$ & References \\
\hline Electrolyte & $\sigma_{\text {éle }}=3.34 \times 10^{4} \exp (-10300 / T)$ & {$[9,13,19]$} \\
Cathode & $\sigma_{\text {cat }}=\frac{4.2 \times 10^{7}}{T} \exp (-1200 / T)$ & {$[9,13,19]$} \\
Anode & $\sigma_{a n}=\frac{9.5 \times 10^{7}}{T} \exp (-1150 / T)$ & {$[9,13,19]$} \\
Interconnector & $\sigma_{\text {intc }}=\frac{9.3 \times 10^{5}}{T} \exp (-1100 / T)$ & {$[9,13,19]$} \\
\hline
\end{tabular}

The heat source due to the activation loss $\left(S_{A c t}\right)$ that is present in the two electrolyte/electrode interfaces is defined by the product of the current density and the activation loss. Eq. 3.

$$
S_{\text {Act }}=\eta_{\text {Act }} \cdot i
$$

where, the activation loss $\left(\eta_{a c t}\right)$ is given by the following equation:

$$
\eta_{A c t, j}=\frac{R \cdot T}{\alpha \cdot n \cdot F} \cdot \sinh ^{-1}\left(\frac{i}{i_{0, j}}\right), j=\text { anode, cathode }
$$

where, $\mathrm{R}$ is the perfect gas constant, $\mathrm{n}$ is the transfer electrons number, $\mathrm{F}$ is the Faraday number, $\alpha$ is the electronic transfer coefficient or the charge transfer coefficient and $i_{0}$ is the exchange current density for each electrode (anodic and cathodic). The exchange current density is given by the following equation.

$$
i_{0, j}=k_{j} . \exp \left(-\frac{E_{j}}{R \cdot T}\right), j=\text { anode }, \text { cathode }
$$

$\mathrm{k}_{\mathrm{j}}$ and $\mathrm{E}_{\mathrm{j}}$ represent the pre-exponential factor and the activation energy of each electrode which are respectively defined by a first-order polynomial temperature function and a constant in Table 3 .

Table 3. Values and expressions of the pre-exponential factor and activation energy $[9,25,26]$

\begin{tabular}{cccc}
\hline \multicolumn{2}{c}{ Anode } & \multicolumn{2}{c}{ Cathode } \\
\hline $\mathrm{k}_{\text {an }}\left[\mathrm{A} \cdot \mathrm{m}^{-2}\right]$ & $\mathrm{E}_{\mathrm{an}}\left[\mathrm{J} . \mathrm{mol}^{-1}\right]$ & $\mathrm{k}_{\mathrm{cat}}\left[\mathrm{Am}^{-2}\right]$ & $\mathrm{E}_{\mathrm{cat}}\left[\mathrm{J} \cdot \mathrm{mol}^{-1}\right]$ \\
\hline $6.54 \times 10^{11} \cdot \frac{R . T}{2 . F}$ & $1.4 \times 10^{5}$ & $2.35 \times 10^{11} \cdot \frac{R . T}{2 . F}$ & $1.37 \times 10^{5}$ \\
\hline
\end{tabular}

The heat source due to the concentration loss $\left(S_{C o n}\right)$ in the two electrodes is defined by the product of the current density and the activation loss. Eq. 6.

$$
S_{\text {Con }}=\eta_{\text {Con }} \cdot i
$$

The concentration loss $\left(\eta_{c o n}\right)$ is given by the following equation:

$$
\eta_{c o n, j}=-\frac{R \cdot T}{n \cdot F} \cdot \ln \left(1-\frac{i}{i_{l, j}}\right), j=\text { anode, } \text { cathode }
$$

$i_{1, j}$ is the limit current of each electrode. The values of the anodic and cathodic limit currents are given in Table 4.

Table 4. The limit current values in each electrode

\begin{tabular}{ccc}
\hline Anode $\left[\mathbf{A}^{-m^{-2}}\right]$ & Cathode $_{\left[\mathbf{A} \cdot \mathbf{m}^{-2}\right]}$ & References \\
\hline $2.99 \times 10^{4}$ & $2.16 \times 10^{4}$ & {$[9,27,28]$} \\
\hline
\end{tabular}

The electrochemical heat source due to the water formation in the anode/electrolyte interface $\left(S_{\text {elec }}\right)$ is given by Eq. 8 .

$$
S_{\text {elec }}=\frac{Q_{\text {elec }}}{2 . F} \frac{i}{\delta}
$$

where, $\delta$ is the reaction zone thickness $(5 \mu \mathrm{m})$ and $\mathrm{Q}_{\text {elec }}$ is the generated heat by the electrochemical reaction of water formation. The generated heat is given by the product of the entropy variation and temperature [29]. Eq. (9):

$$
Q_{\text {elec }}=-T . \Delta S
$$

The entropy variation $\Delta \mathrm{S}$ is calculated by the following equation:

$$
\Delta S_{\mathrm{H}_{2} \mathrm{O}}=S_{\mathrm{H}_{2} \mathrm{O}}-S_{\mathrm{H}_{2}}-\frac{1}{2} S_{\mathrm{O}_{2}}
$$

The entropies of the three species (hydrogen, oxygen and water steam) are calculated by Eq. 11. For a reference temperature of $298.15 \mathrm{~K}$, the hydrogen, oxygen and water steam entropies are given in Table 5. 
The specific heats $\left(\mathrm{C}_{\mathrm{p}}\right)$ of each species are determined from Eq. (12).

$$
\begin{gathered}
S_{j}=S_{j, 298.15}+\int_{298.15}^{T} \frac{C_{p}}{T} d T \\
C_{p}=a_{1} T^{b_{1}}+a_{2} T^{b_{2}}+a_{3} T^{b_{3}}+a_{4} T^{b_{4}}
\end{gathered}
$$

Table 5. Entropy of each species [30, 31]

\begin{tabular}{cc}
\hline Species & Entropy $\left(\mathbf{J}_{\text {.mol }}^{\mathbf{- 1}} \cdot \mathbf{K}^{\mathbf{- 1}}\right)$ \\
\hline $\mathrm{H}_{2} \mathrm{O}($ steam $)$ & 188.83 \\
$\mathrm{H}_{2}$ & 130.59 \\
$\mathrm{O}_{2}$ & 205.14 \\
\hline
\end{tabular}

The empirical constants $a_{k}$ and $b_{k}$ used in Eq. (12) are given for each species by Table 6 .

Table 6. Empirical constants $a_{k}$ and $b_{k}$ of each species [30, 31]

\begin{tabular}{cccc}
\hline Species & $\mathbf{H}_{\mathbf{2}} \mathbf{O}$ (steam) & $\mathbf{H}_{\mathbf{2}}$ & $\mathbf{O}_{\mathbf{2}}$ \\
\hline $\mathbf{a}_{1}$ & 143.05 & 56.505 & 37.432 \\
$\mathbf{b}_{1}$ & 0 & 0 & 0 \\
$\mathbf{a}_{2}$ & -58.040 & -22222.6 & $2.0102 * 10^{-5}$ \\
$\mathbf{b}_{2}$ & 0.25 & -0.75 & 1.5 \\
$\mathbf{a}_{3}$ & 8.2751 & 116500 & -178570 \\
$\mathbf{b}_{3}$ & 0.5 & -1 & -1.5 \\
$\mathbf{a}_{4}$ & -0.036989 & -560700 & 2368800 \\
$\mathbf{b}_{4}$ & 1 & -1.5 & -2 \\
\hline
\end{tabular}

\section{RESULTS AND DISCUSSION}

According to the AS-IT-SOFC model presented in the previous section, a FORTRAN program has been developed locally to investigate and study the planar AS-IT-SOFC overheating. In this part, we expose the influence of each heat source type (without source, Ohmic source, activation source, concentration source, electrochemical source, the sum of two sources Ohmic and activation and the total source) on the maximum temperature values and their distribution.

The cell heart component dimensions are given by $500 \mu \mathrm{m}$ for the anode [22, 32], $40 \mu \mathrm{m}$ for the electrolyte [32, 33], and $50 \mu \mathrm{m}$ for the cathode $[32,34]$. The thermal and electrical conductivities of the anode, electrolyte and cathode are identical to those of the standard materials (Ni-YSZ), (YSZ), (LSM) respectively, as we as also use a density value of an imposed current of 20000 A.m ${ }^{-2}[22,32,35]$.
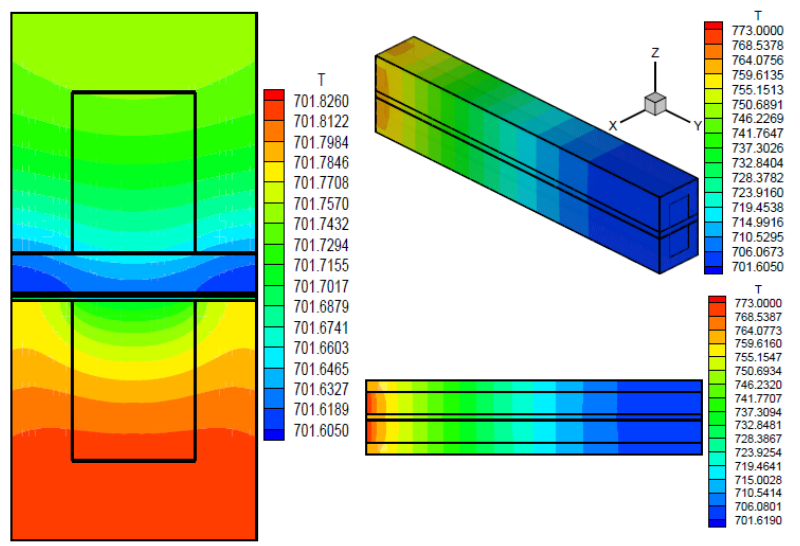

Figure 2. Cell temperature fields for the case without source

\subsection{Without heat source}

Figure 2 shows the temperature fields of a planar IT-SOFC at a gas inlet temperature of $773 \mathrm{~K}$ for the non-heat generation case. The maximum temperature is located at the cell entrance; it is that of the two gases (fuel and oxidant). The decreasing of temperature values is clearly noteworthy from the input to the output of the cell. The minimum temperature is positioned at the right and left sides of the electrolyte upper part and the cathode lower part; it is in order of 701,605 K. The maximum difference between the temperature values is approximately $71.395 \mathrm{~K}$. In addition, the temperature values on the anode side are greater than the temperature values of the cathode side.

\subsection{Heat source due to concentration loss}

Figure 3 shows the temperature fields of a planar AS-ITSOFC using a gas inlet temperature of $773 \mathrm{~K}$ for a heat generation case by the concentration source in both electrodes. The maximum temperature is located at the cell inlet; it is that of both gases (hydrogen and air). The decreasing of temperature values is clearly remarkable from the input to the output of the cell. The minimum temperature is positioned at the right and left sides of the electrolyte upper part and the cathode lower part; it is in order of 701,822 K. The maximum difference between the temperature values is approximately to $71.178 \mathrm{~K}$. In addition, the temperature values in the anodic part are greater than the temperature values of the cathodic part. A slight increase in the temperature values is produced compared to the without-source case of $(0.217 \mathrm{~K})$, which leads to the negligence of the concentration term as a heat source.
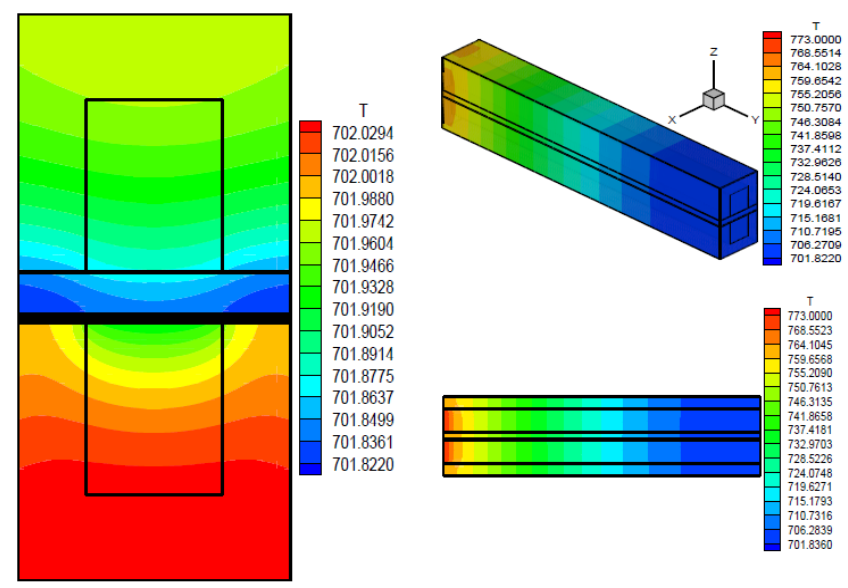

Figure 3. Cell temperature fields according to the concentration source

\subsection{Heat source due to activation loss}

Figure 4 shows the temperature fields of a planar AS-ITSOFC according to a gas inlet temperature of $773 \mathrm{~K}$ for a heat generation case by the activation source. The maximum temperature is located at the cell inlet; it is that of the two gases (fuel and oxidant). The decreasing in temperature values is clearly noteworthy from the input to the output of the AS-ITSOFC. The minimum temperature is positioned at the right and left sides of the electrolyte upper part and the cathode lower part; it is around 709,197 K. The maximum difference between the temperature values in the cell is approximately $63,803 \mathrm{~K}$. In addition, the temperature values in the anodic part are greater than the temperature values in the cathodic part. 


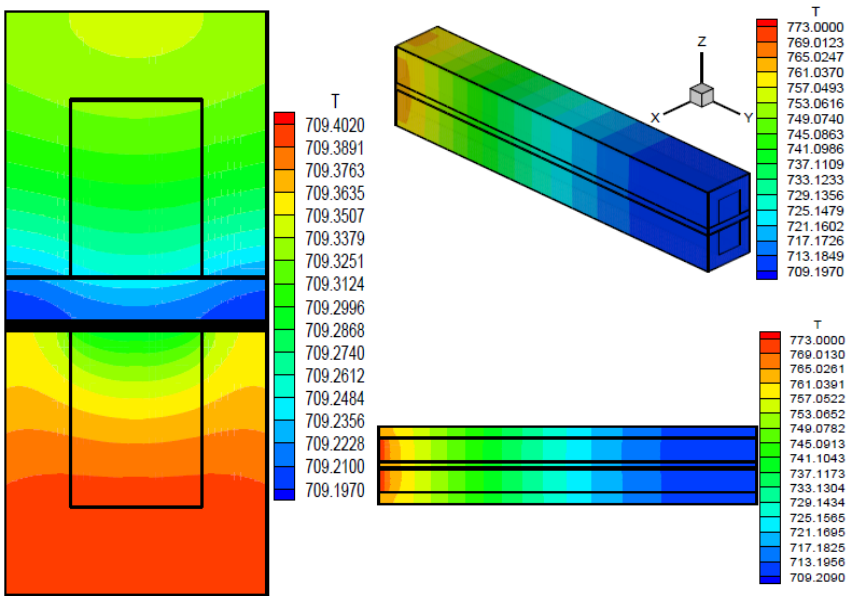

Figure 4. Cell temperature fields according to the activation source

\subsection{Heat source due to electrochemical loss}

Figure 5 shows the temperature fields of a planar AS-ITSOFC using a gas inlet temperature of $773 \mathrm{~K}$ for a heat generation case by the source due to the water formation in the anode (electrochemical source). The maximum temperature is located at the cell inlet; it is that of the fuel and oxidant.

The decreasing in temperature values is clearly shown from the input to the output of the cell. The minimum temperature is positioned at the right and left sides of the electrolyte upper part and the cathode lower part. It is in order of $730,290 \mathrm{~K}$. The maximum difference between the temperature values is approximately $42,710 \mathrm{~K}$. In addition, the temperature values in the anodic part are greater than the temperature values of the cathodic part. Figure 5 .

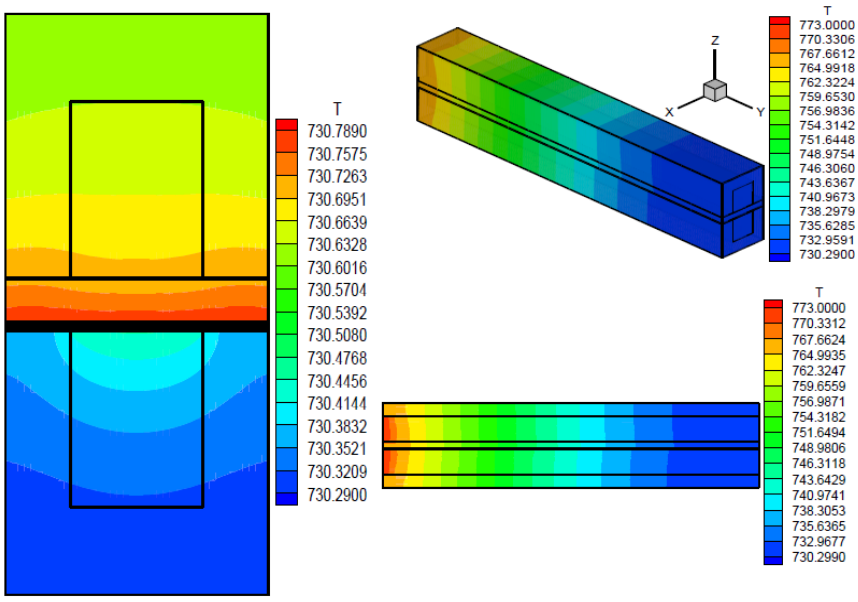

Figure 5. Cell temperature fields according to the electrochemical source

\subsection{Heat source due to Ohmic loss}

Figure 6 shows the temperature fields of a planar AS-ITSOFC using a gas inlet temperature of $773 \mathrm{~K}$ for a heat generation case by the Ohmic source.

In the temperature fields that are shown in Figure 6, we notice that a large heat amount is produced in the along the cell length. The maximum temperature value is higher than that of the reactants at the cell inlet $(841.076 \mathrm{~K})$. The maximum temperature is positioned at the right and left sides of the electrolyte upper part and the cathode lower part. The minimum temperature is located at the inlet of the anodic and cathodic channels; it is that of the two reactive gases $(773 \mathrm{~K})$. The maximum difference between the temperature values is approximately $68.076 \mathrm{~K}$. In addition, it is noted that the temperature values in the anodic part are greater than the temperature values at the cathodic part.

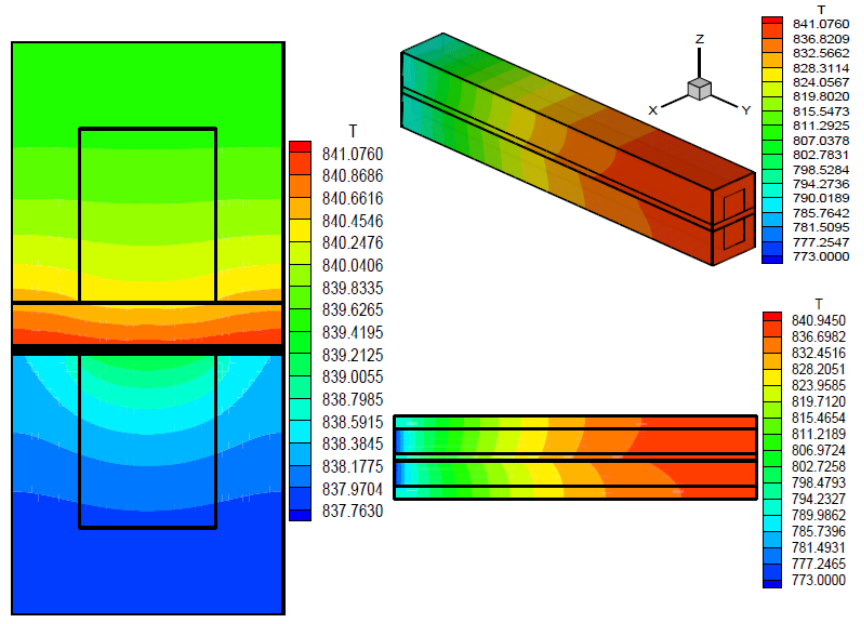

Figure 6. Cell temperature fields according to the ohmic source

\subsection{Heat source due to sum of Ohmic and activation losses}

Figure 7 shows the temperature fields of a planar AS-ITSOFC using a gas inlet temperature of $773 \mathrm{~K}$ for a heat generation case by the sum of the Ohmic and activation sources.

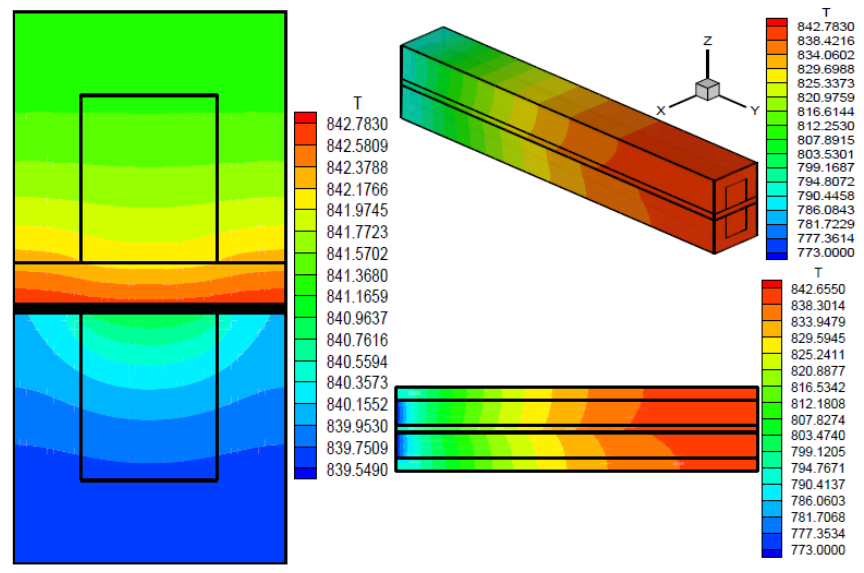

Figure 7. Cell temperature fields according to the ohmic and activation source

In the temperature fields shown in Figure 7, we notice that a significant heat generation is produced by both sources in the along the cell length. The maximum temperature value is about to $842.783 \mathrm{~K}$. The maximum temperature is positioned at the right and left sides of the electrolyte upper part and the cathode lower part. The minimum temperature is located at the inlet of the anode and cathode channels, it is that of the two reactive gases $(773 \mathrm{~K})$. The maximum difference between the temperature values is approximately $69.783 \mathrm{~K}$. In addition, it is noted that the temperature values in the anodic part are greater than the temperature values of the cathodic part. 


\subsection{Total heat source}

Figure 8 shows the temperature fields of a planar AS-ITSOFC using a gas inlet temperature of $773 \mathrm{~K}$ for the heat production case by the sum of the three sources: Ohmic, activation and electrochemical.

In the temperature fields shown in Figure 8, we notice that a large amount of heat production along the cell length is caused by the three sources. The maximum temperature value is about to $852,874 \mathrm{~K}$. The maximum temperature is positioned at the right and left sides of the electrolyte upper part and the cathode lower part. The minimum temperature is located at the inlet of the anode and cathode channels, it is that of the two reactive gases $(773 \mathrm{~K})$. The maximum difference between the temperature values is approximately $79,874 \mathrm{~K}$. In addition, it is noted that the temperature values in the anodic part are greater than the temperature values of the cathodic part.
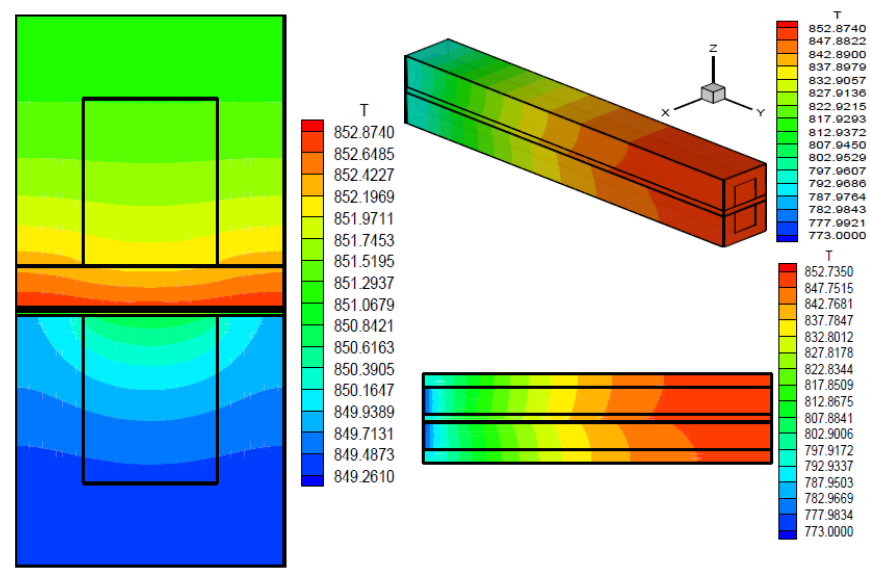

Figure 8. Cell temperature fields according to the total source

\subsection{Comparison between the different heat sources}

Figure 9 shows the temperature evolution at the medium of electrolyte along the $\mathrm{OZ}$ axis according to the different heat sources: without source, activation source, electrochemical source, Ohmic source, two sources (activation and Ohmic) and total source. From Figure 9a it is noted that the three obtained curves (without source, activation source and electrochemical source) having almost the same form. The temperature values lowering is clearly visible; at the cell inlet the temperature value remains constant within a distance of one millimeter, then a values parabolic collapse develops the rest of the cell length. The heat production by the electrochemical source is greater than that produced by the activation source, which is clearly remarkable in Figure 9a.

Figure $9 \mathrm{~b}$ shows that the three curves obtained for the three tests (one source (Ohmic), two sources (Ohmic and activation) and three sources (Ohmic, activation and electrochemical)) having almost the same form. The temperature values elevation is very clear from the input to the output of the cell; at the cell inlet the temperature value remains constant in a distance of one millimeter, then an increase is carried hyperbolically over the cell length rest. The difference between the temperature values of each position of the three cases remains constant in the first millimeter, and then it increases the cell length rest.

The heat production by the Ohmic source is better than that produced by the activation and electrochemical sources, which is clearly remarkable in Figure 9a and Figure 9b.
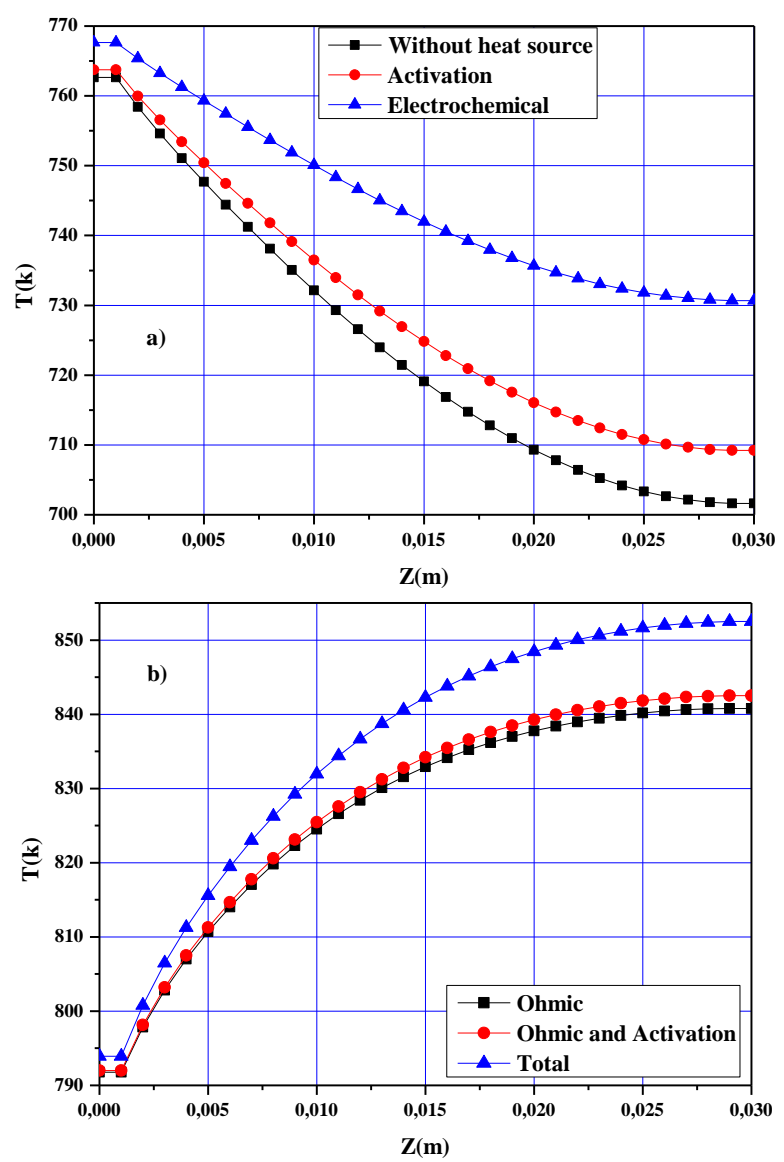

Figure 9. Temperature evolution at the electrolyte medium (x $=0.5 \times$ Max) along the $\mathrm{OZ}$ axis according to the different heat sources. a) Without source, activation and electrochemical sources, b) ohmic, two sources (activation and ohmic) and total source

Figure 10 shows the evolution of the maximum temperature at the AS-IT-SOFC outlet according to the gas inlet temperature for the cases: without source, Ohmic source, activation source, the sum of the Ohmic and activation source, electrochemical source and total source. From Figure 10, it is noticed for the cases without source, activation source and electrochemical source that the curves presented have almost the same form. The maximum temperature at the cell output grows quasi-linearly according to the gases inlet temperatures. The maximum temperature at the cell output of the electrochemical source case is greater than that generated by the activation source, regardless of the gases inlet temperature value.

The evolution of the maximum temperature at the cell outlet according to the gas inlet temperature for the Ohmic source cases, the sum of the Ohmic and activation sources and the total source are the same form. The maximum temperature at the cell outlet is parabolically developing according to the gas inlet temperatures. The maximum temperature at the cell output produced by the Ohmic source is greater than that generated by the electrochemical and activation sources regardless the gas inlet temperature value. Figure 10.

Note that the evolution of the maximum temperature at the AS-IT-SOFC outlet obtained in the total source case has the same evolution way of the Ohmic source case. For a gas inlet temperature of $773 \mathrm{~K}$, the Ohmic source contribution is around $85 \%$ and it is almost $80 \%$ for a gas inlet temperature of $883 \mathrm{~K}$, 
which proves that the Ohmic heat source is the most likely of the overheating of AS-IT-SOFC. Figure10.

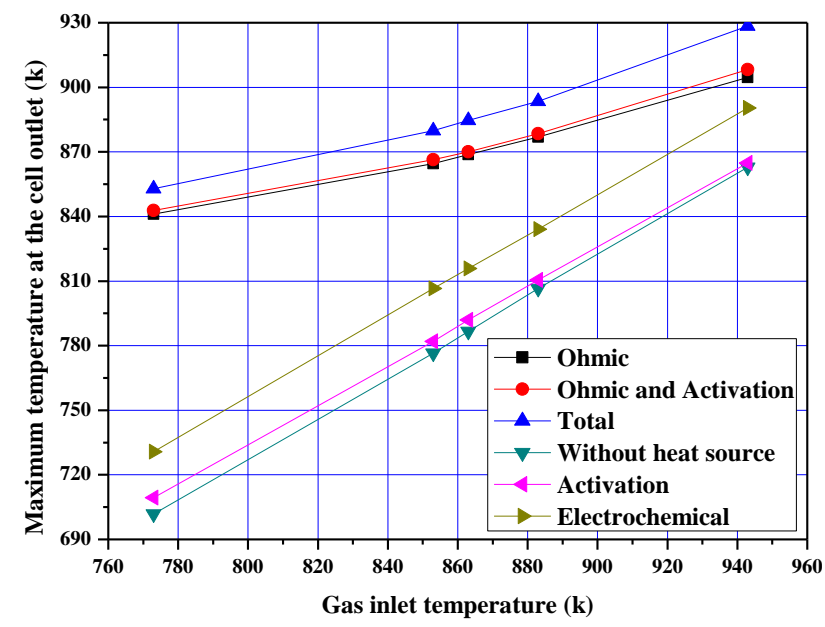

Figure 10. Evolution of the maximum temperature at the cell outlet according to the gas inlet temperatures

\section{CONCLUSIONS}

In this work, we present a thermal study of the heat production phenomenon in an elementary cell of a planar ASIT-SOFC. Our objective is to obtain and determine the impact and contribution of each heat source (Ohmic, activation, concentration and electrochemical) on the distribution and elevation of the temperature values in all parts of the AS- ITSOFC (electrolyte, anode, cathode, the two anodic and cathodic interconnectors and the two channels). The results are obtained using a FORTRAN language program developed locally, which is based on the modeling of the governing equations of the equilibrium heat transfer phenomenon in a three-dimensional environment using the finite differences method according to a centered scheme.

The obtained results for the cases which consider the heat production by the Ohmic sources, the sum of the two sources Ohmic and activation and the total source show that the highest temperatures are localized in the zones of the electrolyte farthest from the channels that are in the neighboring the cathode at the cell output. The lower temperatures are positioned at the inlet of the two anodic and cathodic channels. For the case that considers heat production by concentration, activation and electrochemical sources, the lower temperatures are localized at the cell output in the electrolyte zones farthest from the channels that are closer to the cathode, and the highest temperatures are positioned at the inlet of the two AS-IT-SOFC channels. The greatest heat production is that generated by the Ohmic source. The smallest heat production is that obtained by the concentration source, which is really negligible compared to the other sources. The heat produced by the electrochemical source is greater than that produced by the activation source.

For a gas inlet temperature of $883 \mathrm{~K}$, the contributions of the Ohmic, activation, concentration and electrochemical heat sources in the evolution in the temperature values are respectively $80.604,0.099,2.296$ and $17.001 \%$. This proves that the heat source due to the Joule's effect is the most responsible for the heat generation inside the AS-IT-SOFC.

As a perspective of the present work, an optimization study of the AS-IT-SOFC overheating according to the operational and dimensional parameters will be envisaged for the minimization of the heat production inside the AS-IT-SOFCs, which logically will allow an improvement of the electrical production and lifetime of these fuel cells.

\section{REFERENCES}

[1] Yokokawa, H. (2009). Overview of intermediatetemperature solid oxide fuel cells. In Fuel Cells and Hydrogen Energy, Springer, 17-43. https://doi.org/10.1007/978-0-387-77708-5 2

[2] Hossain, S., Abdalla, A.M., Jamain, S.N.B., Zaini, J.H., Azad, A.K. (2017). A review on proton conducting electrolytes for clean energy and intermediate temperature-solid oxide fuel cells. Renewable and Sustainable Energy Reviews, 79: 750-764. https://doi.org/10.1016/j.rser.2017.05.147

[3] Sohn, S., Baek, S.M., Nam, J.H., Kim, C.J. (2016). Twodimensional micro/macroscale model for intermediatetemperature solid oxide fuel cells considering the direct internal reforming of methane. Int. J. Hydrog. Energy, 41(12):

$5582-5597$ https://doi.org/10.1016/j.ijhydene.2016.01.161

[4] Yang, C., Yang, G.G., Yue, D.T., Yuan, J.L., Sunden, B. (2013). Computational fluid dynamics model development on transport phenomena coupling with reactions in intermediate temperature solid oxide fuel cells. Journal of Renewable and Sustainable Energy, 5(2) 021420. https://doi.org/10.1063/1.4798789

[5] Lee, S.F., Hong, C.W. (2010). Multi-scale design simulation of a novel intermediate temperature micro solid oxide fuel cell stack system. Int. J. Hydrog. Energy, 35(3): $1330-1338$ https://doi.org/10.1016/j.ijhydene.2009.11.095

[6] Andersson, M., Yuan, J., Sundén, B. (2014). SOFC cell design optimization using the finite element method based CFD approach. Fuel Cells, 14(2): 177-188. https://doi.org/10.1002/fuce.201300160

[7] Sahli, Y., Zitouni, B., Ben-Moussa, H. (2017). Solid oxide fuel cell thermodynamic study. Çankaya University Journal of Science and Engineering, 14(2): 134-151.

[8] Sahli, Y., Zitouni, B., Ben-Moussa, H. (2018). Thermodynamic optimization of the solid oxyde fuel cell electric power. UPB Sci Bull Ser B Chem Mater Sci., 80(2): 159-170.

[9] Sahli, Y., Ben-Moussa, H., Zitouni, B. (2019). Optimization Study of the Produced Electric Power by SOFCs. International Journal of Hydrogen Energy, 44(39): 22445-22454 https://doi:10.1016/j.ijhydene.2018.08.162

[10] Zitouni, B., Ben Moussa, H., Oulmi, K. (2007). Studying on the increasing temperature in IT-SOFC: Effect of heat sources. Journal of Zhejiang University SCIENCE A, 9: 1500-1504. https://doi.org/10.1631/jzus.2007.A1

[11] Zitouni, B., Ben Moussa, H., Oulmi, K., Saighi, S., Chetehouna, K. (2009). Temperature field, $\mathrm{H}_{2}$ and $\mathrm{H}_{2} \mathrm{O}$ mass transfer in SOFC single cell: Electrode and electrolyte thickness effects. International Journal of Hydrogen Energy, 34(11): 5032-5039. https://doi.org/10.1016/j.ijhydene.2008.12.085

[12] Zitouni, B., Andreadis, G.M., Ben Moussa, H., Abdenebi, H., Haddad, D., Zeroual, M. (2011). Two-dimensional 
numerical study of temperature field in an anode supported planar SOFC: Effect of the chemical reaction. International Journal of Hydrogen Energy, 36(6): 42284235. https://doi.org/10.1016/j.ijhydene.2010.07.141

[13] Oulmi, K., Zitouni, B., Ben Moussa, H., Abdenebi, H., Andreadis, G.M. (2011). Total polarization effect on the location of maximum temperature value in planar SOFC. International Journal of Hydrogen Energy, 36(6): 42364243. https://doi.org/10.1016/j.ijhydene.2010.07.107

[14] Abdenebi, H., Zitouni, B., Haddad, D., Ben Moussa, H., George, M.A., Abdessemed, S. (2011). SOFC fuel cell heat production: Analysis. Energy Procedia, 6: 643-650. https://doi.org/10.1016/j.egypro.2011.05.074

[15] Ben Moussa, H., Zitouni, B., Oulmi, K., Mahmah, B., Belhamel, M., Mandin, P. (2009). Hydrogen consumption and power density in a co-flow planar SOFC. International Journal of Hydrogen Energy, 34(11): 5022-5031.

https://doi.org/10.1016/j.ijhydene.2008.12.034

[16] Haddad, D., Abdenebi, H., Zitouni, B., Ben Moussa, H., Oulmi, K. (2013). Thermal field in SOFC fed by hydrogen: Inlet gases temperature effect. International Journal of Hydrogen Energy, 38(20): 8575-8583. https://doi.org/10.1016/j.ijhydene. 2013.01.004

[17] Abdenebi, H., Zitouni, B., Ben Moussa, H., Haddad, D. (2015). Thermal field in SOFC fed by CH4: Molar fractions effect. Journal of the Association of Arab Universities for Basic and Applied Sciences 17: 82-89. https://doi.org/10.1016/j.jaubas.2014.01.002

[18] Abdenebi, H., Zitouni, B., Ben Moussa, H., Haddad, D., Zitouni, H., Sahli, Y. (2015). Inlet methane temperature effect at a planar SOFC thermal field under direct internal reforming condition. In Progress in clean energy volume II: Novel Systems and Applications, Springer, pp. 567581. https://doi.org/10.1007/978-3-319-17031-2_41

[19] Sahli, Y., Zitouni, B., Ben Moussa, H., Abdenébi, H. (2015). Three-dimensional numerical study of the heat transfer on the planar solid oxide fuel cell: Joule's effect. In Progress in clean energy volume I: Analysis and Modeling, Springer, pp. 449-461. https://doi.org/10.1007/978-3-319-16709-1 32

[20] Chyou, Y.P., Chung, T.D., Chen, J.S., Shie, R.F. (2005). Integrated thermal engineering analyses with heat transfer at periphery of planar solid oxide fuel cell. Journal of Power Sources, 139: 126-140. https://doi.org/10.1016/j.jpowsour.2004.07.001

[21] Ramakrishna, P.A., Yang, S., Sohn, C.H. (2006). Innovative design to improve the power density of a solid oxide fuel cell. Journal of Power Sources, 158: 378-384. https://doi.org/10.1016/j.jpowsour.2005.10.030

[22] Damm, D.L., Fedorov, A.G. (2006). Reduced-order transient thermal modeling for SOFC heating and cooling. Journal of Power Sources, 159: 956-967. https://doi.org/10.1016/j.jpowsour.2005.11.072

[23] Kakaç, S. Pramuanjaroenkij, A., Zhou, X.Y. (2007). A review of numerical modeling of solid oxide fuel cells. International Journal of Hydrogen Energy, 32(7): 761786. https://doi.org/10.1016/j.ijhydene.2006.11.028

[24] Sangtongkitcharoen, W., Vivanpatarakij, S., Laosiripojana, N., Arpornwichanop, A., Assabumrungrat, S. (2008). Performance analysis of methanol-fueled solid oxide fuel cell system incorporated with palladium membrane reactor. Chemical Engineering Journal,
138(1-3): 436-441.

https://doi.org/10.1016/j.ijhydene.2009.02.049

[25] Andersson, M., Nakajima, H., Kitahara, T., Shimizu, A., Koshiyama, T., Paradis, H., Yuan, J., Sundén, B. (2014). Comparison of humidified hydrogen and partly prereformed natural gas as fuel for solid oxide fuel cells applying computational fluid dynamics. International Journal of Heat and Mass Transfer, 77: 1008-1022. https://doi.org/10.1016/j.ijheatmasstransfer.2014.06.033

[26] Saidi, M., Siavashi, F., Rahimpour, M.R. (2014). Application of solid oxide fuel cell for flare gas recovery as a new approach: A case study for Asalouyeh gas processing plant, Iran. Journal of Natural Gas Science \& Engineering, 17: 13-25. https://doi.org/10.1016/j.jngse.2013.12.005

[27] Zhang, X.Q., Su, S.H., Chen, J.C., Zhao, Y.R., Brandon, N. (2011). A new analytical approach to evaluate and optimize the performance of an irreversible solid oxide fuel cell-gas turbine hybrid system. International Journal of Hydrogen Energy, 36(23): 15304-15312. https://doi.org/10.1016/j.ijhydene.20 11.09.004

[28] Zhang, X.Q., Wang, Y., Guo, J.C., Shih, T.M., Chen, J.C. (2014). A unified model of high-temperature fuel-cell heat-engine hybrid systems and analyses of its optimum performances. International Journal of Hydrogen Energy, 39(4): $1811-1825$ https://doi.org/10.1016/j.ijhydene.2013.11.027

[29] Lu, Y.X., Schaefer, L., Li, P.W. (2005). Numerical study of a flat-tube high power density solid oxide fuel cell Part I. Heat/mass transfer and fluid flow. Journal of Power Sources, 140(2): 331-339. https://doi.org/10.1016/j.jpowsour.2004.08.036

[30] Naraharisetti, P.K., Lakshminarayanan, S., Karimi, I.A. (2014). Design of biomass and natural gas based IGFC using multi-objective optimization. Energy, 73: 635-652. https://doi.org/10.1016/j.energy.2014.06.061

[31] Yang, W.Y., Zhao, Y.R., Liso, V., Brandon, N. (2014). Optimal design and operation of a syngas-fuelled SOFC micro-CHP system for residential applications in different climate zones in China. Energy and Buildings, 80: 613-622.

https://doi.org/10.1016/j.enbuild.2014.05.015

[32] Aguiar, P., Adjiman, C.S., Brandon, N.P. (2004). Anodesupported intermediate temperature direct internal reforming solid oxide fuel cell. I: model-based steadystate performance. Journal of Power Sources, 138: 120136. https://doi.org/10.1016/j.jpowsour.2004.06.040

[33] Bao, C., Cai, N.S., Croiset, E. (2011). A multi-level simulation platform of natural gas internal reforming solid oxide fuel cell-gas turbine hybrid generation system-Part II. Balancing units model library and system simulation. Journal of Power Sources, 196(20): 84248434. https://doi.org/10.1016/j.jpowsour.2011.05.032

[34] Ferguson, J.R., Fiard, J.M., Herbin, R. (1996). Three dimensional numerical simulation for various geometries of solid oxide fuel cells. Journal of Power Sources, 58(2): 109-222. https://doi.org/10.1016/0378-7753(95)02269-4

[35] Wongchanapai, S., Iwai, H., Saito, M., Yoshida, H. (2012). Selection of suitable operating conditions for planar anode-supported direct-internal-reforming solidoxide fuel cell. Journal of Power Sources, 204: 14-24. https://doi.org/10.1016/j. jpowsour.2011.12.029 